\title{
Responsabilidade civil por dano direito ambiental
}

\section{Civil responsibility for environmental damage}

\author{
MÁrCio Bonini Notari \\ Universidade do Contestado/RS
}

Resumo O presente trabalho foi elaborado com o objetivo de melhor conhecer as leis que regulamentam nosso Direito Ambiental, trazendo informações relevantes a respeito do tema. Desde seu princípio, na segunda metade do século XX, essas inovações já visavam garantir o equilíbrio entre o desenvolvimento sustentável com a qualidade de vida do ser humano, tanto para a geração da época, como também para as futuras, para que todos pudessem desfrutar dos recursos naturais tão ricos para a saúde humana. Para tanto, a constituição pátria colocou direitos e deveres oportunos a todos, pois o dever de manter um meio ambiente ecologicamente sustentável não é apenas do governo, mas também de toda a sociedade, levando como base o princípio da prevenção e da precaução, impondo, assim, que se nem todos cumprirem com essas normas terão que, de alguma forma, reparar o dano que causaram, seja pessoa física ou jurídica. Os instrumentos que a lei dispõe para questões desse cunho é a ação civil pública e a ação popular, que são os meios legais para a solução do problema. Desse modo, o agente poluidor responderá por seus atos, com a finalidade de sempre buscar o resgate do estado em que se encontrava o ambiente antes de ser atingido, procurando, principalmente, a prevenção, pois em muitas vezes o dano é muito difícil ou, até mesmo, impossível de ser reparado. Portanto, a educação ambiental e o conhecimento das leis devem ser trabalhados pelo governo na sociedade, para que se tenha um maior controle sobre os riscos que possam causar potencial perigo ao meio ambiente.

Palavras-chave: Direito ambiental. Meio ambiente. Responsabilidade civil. Dano AMBIENTAL. ConsCIENTIZAÇão.

Abstract The present work was designed to better understand the laws that regulate our
Environmental Law, bringing relevant information about the theme from the beginning, in
the second half of the twentieth century, these innovations were already aimed at ensuring
the balance between sustainable development and quality of life of the human being, for
the generation of the time, as well as for the future, so that everyone could enjoy the natural
resources so rich for human health. To this end, the country's constitution has given every-
one the right and duty to do so, since the duty to maintain an environmentally sustainable
environment is not only a duty of the government but also of society as a whole, based on
the principle of prevention and precaution, so that if not all comply with these standards 
will have to somehow repair the damage they caused, whether individual or legal. The instruments that the law provides for such matters are public civil action and popular action, which are the legal means to solve the problem. In this way, the pollutant agent will respond for his actions, and always the purpose will be to seek the rescue of the state in which the environment was before being hit, but mainly seek prevention, as in many times the damage is very difficult to repair or even impossible. Therefore, environmental education, and knowledge of laws must be worked by government in society, so that one can have greater control over the risks of potentially causing danger to the environment.

Keywords: Environmental law. Environment. Civil liability. Environmental daMAGE. AWARENESS.

\section{INTRODUÇÃo}

São muitas as preocupações relacionadas ao meio ambiente, já que, pouco a pouco, pode-se apurar que infelizmente crescem os crimes contra o meio ambiente, provocando, cada vez mais danos, muitas vezes, irreversíveis, pois o habitat não volta ao seu estado anterior, mesmo havendo programas de preservação. O meio ambiente saudável é fonte de vida, sendo indispensável para o bom desenvolvimento humano. Com isso, á medida que ocorre a degradação, ela não só ameaça o bem-estar como a qualidade de vida humana. Além disso, entra em cena a tutela jurídica ao meio ambiente.

Com a criação da lei 6.938/81, da Política Nacional do Meio Ambiente, foram melhor assegurados os direitos referentes ao meio ambiente, nela estão dispostas normas que regularizam as questões de cunho ambiental, responsabilizando os culpados da melhor maneira, buscando que haja, após a punição a conscientização para que não venha a ocorrer a mesma imprudência ou negligência. Também no artigo 225 da CF/88 há regulamentação legal sobre o tema.

O propósito deste trabalho é esclarecer sobre os riscos que geram danos ambientais á luz da responsabilidade civil. É importante explicar que cabe responsabilidade administrativa e penal, mas no presente trabalho o alvo é a responsabilidade civil por dano, mostrando a existência de leis que controlam o uso dos bens naturais, ainda mais quando se trata de práticas que constituam riscos óbvios, pois, muitas vezes, já existe a certeza do dano, antes mesmo de acontecer.

$\mathrm{O}$ poluidor, assim denominado na $\mathrm{CF} / 88$, será legalmente punido, sob qualquer ato ilícito que vier a praticar ao meio ambiente, e essas penas podem ser privativas de direito ou pecuniárias. As normas que versam sobre o meio ambiente buscam a preservação e/ou a precaução dos danos, procurando estabelecer condenações eficazes quanto á diminuição de tais agravos, que são oriundos da má conduta de quem vier a cometer esse tipo de agressão.

No Brasil, foi adotada a responsabilidade civil objetiva por dano, no entanto, também existe a responsabilidade civil subjetiva. Neste trabalho, nos fixaremos na responsabilidade civil objetiva, contudo, para melhor compreendê-la precisa-se entender as diferenças entre uma e outra, por isso é importante que ambas sejam explicadas. Para tanto, é fundamental o estudo de alguns conceitos e princípios, a fim de que se possa conseguir o mais amplo domínio sobre o assunto em destaque "Responsabilidade Civil Objetiva de Pessoa Jurídica por Dano no Direito Ambiental". 


\section{Responsabilidade CIVIL POR DANO AMBIENTAL}

Depois que a tutela jurídica foi caracterizada como instrumento que deu causa a inúmeras modificações na esfera do Direito, muitas inovações aconteceram com o objetivo de assegurar a sua preservação, como os deveres de conduta que foram colocados a todos. No âmbito internacional, a sustentabilidade ganhou força depois de valiosos documentos das Nações Unidas, por exemplo, o caso conhecido como Relatório de Brundtland, de 1987, que foi feito pela Comissão Mundial do Meio Ambiente, e que interligava a sustentabilidade com o atendimento das necessidades das gerações da época sem comprometer o das futuras gerações.

O Relatório Brundtland, elaborado pela Comissão Mundial sobre o Meio Ambiente e Desenvolvimento em 1987, colocou o conceito de "desenvolvimento sustentável" na agenda política. Indicando a existência de incompatibilidade entre desenvolvimento sustentável e os padrões de produção e consumo existentes, o Relatório traz à discussão a necessidade de uma nova relação entre o ser humano e o meio ambiente. $\mathrm{O}$ modelo apresentado pelo Relatório não propõe a estagnação do crescimento econômico, mas, sim, indica a conciliação entre as questões ambientais e sociais (REMÉDIO; BARBOSA, 2013, p. 15)

A previsão legal à responsabilidade por dano ambiental está no disposto da lei 6.938/81, no artigo. 14, § 1: também, no caput do artigo 14, o dispositivo elenca que sem prejuízo das penalidades definidas pela legislação federal, estadual e municipal o não cumprimento das medidas necessárias à preservação ou correção dos inconvenientes e danos causados pela degradação da qualidade ambiental sujeitará os transgressores:

$\S 1^{\circ}$ - Sem obstar a aplicação das penalidades previstas neste artigo, é o poluidor obrigado, independentemente da existência de culpa, a indenizar ou reparar os danos causados ao meio ambiente e a terceiros, afetados por sua atividade. $\mathrm{O}$ Ministério Público da União e dos Estados terá legitimidade para propor ação de responsabilidade civil e criminal, por danos causados ao meio ambiente. (LEI 6.938/81)

\section{Meio ambiente}

O conceito de meio ambiente está definido no artigo $3^{\circ}$, inciso I, da lei 6.938/81, que diz " meio ambiente é o conjunto de condições, leis, regras, influências e interações de ordem física, química e biológica, que permite, que abriga e rege a vida em todas as suas formas".

Ainda na Constituição Federal no seu artigo. 225 " todos têm direito ao meio ambiente ecologicamente equilibrado, bem de uso comum do povo essencial à sadia qualidade de vida, impondo-se ao Poder Público e à coletividade o dever de defendê-lo e preservá-lo para as presentes e futuras gerações".

Além de estar expresso na lei, é importante que haja a conscientização sobre o valor da preservação do meio ambiente, e ainda saber que para qualquer ato ilícito que for praticado, haverá a devida punição para que, em consequência disso, provoque a redução dos danos gerados ao habitat que é de bem comum, o qual todos teêm o dever de cuidá-lo para que os danos sejam de menor impacto, uma vez que, todos precisam e devem ajudar a preservar a natureza para que as presentes e futuras gerações usufruam dos recursos naturais. 
O meio ambiente está elencado nos direitos chamados de terceira geração peculiarizam-se pela titularidade difusa ou coletiva, uma vez que são concebidos para a proteção não do homem isoladamente. Esse universalismo, porém, dá-se no plano abstrato. Alguns direitos, como o do sufrágio, dependiam de requisitos de riqueza para serem desfrutados. mas de coletividades, de grupos. Tem-se, aqui, o direito à paz, ao desenvolvimento, à qualidade do meio ambiente, à conservação do patrimônio histórico e cultural5. Essa distinção entre gerações dos direitos fundamentais é estabelecida apenas com o propósito de situar os diferentes momentos em que esses grupos de direitos surgem como reivindicações acolhidas pela ordem jurídica (MENDES, 2015, pp. 137-138)

Para que, desde já, se construa uma educação ambiental favorável a todos os seres vivos. Assim, existindo o equilíbrio necessário entre o meio ambiente e o homem, haverá também mais qualidade de vida, direito esse claramente expresso em lei e o qual todos podem usufruir, mas de maneira correta e de acordo com as normas vigentes, para que nem a vida humana, nem o desenvolvimento econômico sejam prejudicados.

\section{Dano ambiental}

Entende-se por dano, segundo Antunes, o prejuízo causado a alguém por terceiro, o qual se vê obrigado ao ressarcimento. O conceito de dano não está expressamente elencado na lei, mas o artigo. $3^{\circ}$, inciso II, da lei 6.938/81, vislumbra o dano a partir da conjugação do conceito de poluição e degradação ambiental.

O dano ambiental abrange desde a apresentação da perda ou deterioração do bem ambiental em si mesmo, na sua condição anterior, até a perda econômica surgida da degradação. Assim, incluem-se tanto os danos que da lesão de um bem ambiental se gerem tanto na coletividade como poderão ser vistos individualmente.

O dano ambiental é caracterizado por alguns aspectos particulares, os quais desafiam a matéria de responsabilidade civil. Uma das características mais relevantes diz respeito à dimensão do detrimento, pois a doutrina tem um olhar restrito pela jurisprudência sobre o dano ambiental. Tal visão trata que não se deve considerar o dano que possa vir a gerar riscos futuros, mas, sim, o dano efetivamente ocorrido. O dever de preservar o meio ambiente, no entanto, não exime a alternativa de que a intervenção humana, no uso de seus recursos naturais, cause algum tipo de degradação.

O dano ambiental configura um aspecto da responsabilidade em matéria ambiental. Decorre de atividade que agrida a natureza ou altere de forma indistinta sua forma pelo homem, acabando por sofrer mutações negativas, ou seja, toda vez que isso acontecer existe a certeza de dano, prejuízo esse que em muitas vezes pode ser irreversível, estabelecendo que o causador fique responsável por repará-lo ou indenizá-lo.

O direito ambiental opera em dois âmbitos diferentes: preventivo e reparador. Por diversas vezes, o dano ambiental torna-se de difícil ou de impossível recomposição, por isso a ação preventiva tem mais destaque na esfera ambiental do que a reparadora. A ação preventiva sempre vai ser usada quando ficar evidente qualquer possível ato que gere potencial perigo ao meio ambiente, para que assim se consiga evitar o dano antes que ele ocorra. Por sua vez, na ação reparadora, o objetivo é tentar resgatar os prejuízos de um dano que já 
se consumou, visando recompor o dano ambiental ou pela condenação de indenização ao poluidor pelos prejuízos que causou.

A reparação do dano ambiental vai acontecer por meio das normas de responsabilidade civil que supõem, dano a outrem, acarretando obrigação de repará-lo, o que equivale em restaurar o bem ambiental danificado ao momento que ele se encontrava antes de ser atingido, sendo através de uma importância em dinheiro ou não.

Ou seja, a reparação do dano consta na obrigatoriedade que o causador da lesão tem de repará-lo. Poluidor é qualquer pessoa física ou jurídica, de direito público ou privado, responsável direta ou indiretamente, por alguma ação que cause degradação ambiental, conforme a responsabilidade civil objetiva. É importante salientar que dano difere de impacto, pois muitas vezes pode ocorrer o impacto sem que ocorra o dano. Um exemplo disso ocorre na atividade de exploração sem licenciamento, ou no caso de lançar na atmosfera ou aos recursos hídricos partículas acima do limite legal. Assim, para que se possa ordenar a reparação é preciso ter havido o estrago.

\section{CONDiÇÕes PARA A IMPUTAÇÃo da RESPONSABILIDAdE PELO DANO AMBIENTAL}

Existe algumas condições específicas para que haja a indenização decorrente do dano ambiental, que são a conexão entre a atividade do poluidor e o dano e nexo de causalidade e o dano. Referente à conexão entre a atividade do poluidor e o dano, a teoria objetiva não coloca como requisito a culpa na ira de indenizar. O risco vai ser tratado como fator de imputação. Mas, mesmo assim, não se exclui a necessidade de verificar a conexão entre a atividade praticada pelo sujeito a quem se deseja imputar a responsabilidade e o dano ocorrido.

Já no que diz respeito a nexo de causalidade, a indagação que deve ser feita entre a atividade desenvolvida pelo autor do dano nem sempre vai precisar de certeza fática, no sentido de quanto foi a contribuição para o resultado final, pois não é sempre que se pode determinar o nexo de causalidade, a relação da causa e efeito entre a atividade realizada e a violação apurada. Conceitualmente, o dano ambiental admite muitas causas, mas nem todas são possíveis de se verificar após a ocorrência. É na ligação entre essas atividades que ocorre a agressão.

No caso de serem vários autores do dano, todos respondem solidariamente, o que ocorrerá de maneira facultativa, podendo entrar com a ação contra um ou todos os causadores, sem a necessidade de todos se apresentarem como réus da ação para a indenização.

Para essa responsabilidade, se não for demonstrado o nexo causal ou a participação individual de cada um na ocorrência do dano, existe algumas medidas usadas para determinar, como o direito comparado, por exemplo o caso de market share liabiti ${ }^{l}$, que dispõe

\footnotetext{
Conforme referido, esta é a hipótese de responsabilidade civil, identificada através da cota de participação no mercado dos potenciais causadores do dano. Tal doutrina foi aplicada, pela primeira vez, no famoso caso Sindell v. Abott Laboratories, em decisão proferida pela Suprema Corte do Estado da Califórnia (Sindell v. Abbot Laboratories), em 1980.134 Tratava-se de demanda envolvendo os efeitos nocivos derivados da ingestão de medicamento contendo o princípio ativo denominado Diethylstilbestrol (DES). Referido princípio ativo era componente de medicamento utilizado por gestantes que tinham histórico de abortos espontâneos. O medicamento havia se revelado eficaz para ajudar as gestantes a evitarem abortos ou nascimentos de bebês prematuros, e foi muito utilizado entre 1941 e 1971, quando a F.D.A. (Food and Drug Administration - agência americana reguladora) proibiu sua fabricação (ALVES, 2018, p. 25)
} 
da responsabilidade em relação aos demais coobrigados que será determinada em relação á participação que cada um teve no mercado. Além disso, outra situação que ocorre é quando o proprietário já tiver comprado um imóvel que tenha sido objeto de degradação não se investiga a culpa, segundo a teoria objetiva.

E, por fim, ainda tem o dano que na responsabilidade civil se ampara no reconhecimento da sua autonomia em correlação a outros danos passíveis de indenização. Desse modo, o sentido de dano ambiental será mais amplo ou ainda mais restrito, envolvendo uma quantidade menor ou maior de bens ambientais reconhecidos. Então, o dano ambiental vai ser determinado conforme os bens ambientais suscetíveis de tutela. Esses danos poderão ser econômicos ou não, todos indenizáveis.

\section{RESPONSABILIDADE CIVIL OBJETIVA}

A Constituição Federal de 1988 dedicou, entre suas inúmeras partes, uma especialmente ao Meio Ambiente, que determina os tipos de formas para a reparação do dano ambiental em três diferentes responsabilidades: civil, penal e administrativa. É importante salientar que elas são independentes e não interferem no procedimento uma da outra.

\footnotetext{
Pode ocorrer a sobreposição das duas modalidades de responsabilidade objetiva. Quer dizer, a lei pode estabelecer, ao lado da norma geral de objetivação do art. 927, parágrafo único, in fine, uma norma específica que a reforce. É o caso, por exemplo, dos empresários fornecedores de produtos. Para eles, o Código Civil objetiva a responsabilidade não somente no preceito geral mencionado, como num específico, o art. 931. Sobrepõem-se, então, no caso de empresários que fornecem ao mercado produtos (os industriais, construtores etc.) as duas modalidades de responsabilidade objetiva: a formal, no art. 931 do CC (e também no art. 12 do $\mathrm{CDC}$ ), e a material, no fim do art. 927, parágrafo único. A norma de responsabilização material, por evidente, pode integrar qualquer diploma legal, e não necessariamente o Código Civil. Assim, há também a sobreposição no caso dos empresários prestadores de serviços, tendo em conta o art. 14 do $\mathrm{CDC}$, e no do Estado, considerando-se o art. 37, § 6 $6^{\circ}$ da CF (COELHO, 2012, p. 687)
}

Porém, nos aprofundaremos na responsabilidade civil. No direito ambiental, a responsabilidade civil coloca a obrigação do sujeito a reparar o dano que causou. Essa obrigação trata-se de uma responsabilização licita, que condena uma conduta ilícita, fazendo que o sujeito que tenha cometido tal infração seja submetido a uma justa punição por omissão ou negligência, que surge de um prejuízo que precisa ser ressarcido.

A responsabilidade civil objetiva também pode ser chamada de pura, nos casos em que o dano acontece por meio de um ato lícito ou de um fato jurídico. Nesse tipo de situação, mesmo que a forma de agir tenha sido lícita, há a obrigação de indenizar, já que o dano causado gerou prejuízo, de acordo com o artigo - 14, §1, da lei 6938/81. Também há a responsabilidade civil impura que ocorre quando existe a obrigação de indenizar, mas por culpa de outros, como acontece quando o empregado causa algum tipo de dano no exercício de suas funções. Nesse caso, o seu empregador terá o dever de indenizar, mesmo não tendo culpa, já que o ato ilícito foi cometido por seu funcionário, Conforme Súmula 341 do Supremo Tribunal Federal. 
No Direito Privado, a teoria do risco integral não é aplicada, mas no ramo do direito ambiental, a nossa doutrina adota essa teoria e não aceita qualquer excludente nas situações que se referirem a danos ambientais. A obrigação de indenizar vai independer de culpa do agente causador para que, assim, se possa resguardar o direito das vítimas nos casos de agressões que gerem danos ao meio ambiente.

Conforme Sirvinskas (2015), a teoria objetiva não exige a demonstração da culpa, isto é, o agente será responsabilizado pelos danos que causar independentemente de culpa. Basta que haja a existência do fato, o dano e o nexo causal. A responsabilização se dá pelo ressarcimento dos danos causados pelo infrator mesmo que o mesmo não tenha agido com culpa. Também, nessa mesma concepção, ocorre a responsabilidade objetiva quando a lei fixa ao agente causador o encargo de indenizar o dano ocasionado sem culpa, valendo-se do nexo causal e do prejuízo, podendo em alguns casos a culpa ser presumida prescindível.

A Teoria Objetiva por dano no direito ambiental pode ter duas linhas de alcance. Uma segue que a responsabilidade objetiva fomente adaptar alguns danos que estão ligados aos interesses coletivos ou difusos, com a ânsia da própria sociedade. Porém, observando por outro ângulo, a responsabilidade objetiva procura a integração do dano com o lucro, levando em consideração que mesmo aquele que cometer alguma atividade lícita, ainda assim, pode gerar prejuízos ao meio ambiente, e deve então responder pelo risco, sem ter que provar a culpa do agente.

\section{Conceito de direito ambiental}

O conceito de direito ambiental pode ser entendido como um conjunto de normas e princípios que visam a preservação do meio ambiente sadio e equilibrado, essencial à qualidade de vida.

O Direito Ambiental tem como fim ordenar quem pode usar os recursos naturais, durante quanto tempo e qual a quantidade e maneira como vai ser usado. Nos termos de Paulo Affonso Leme Machado, o direito ambiental é um direito sistematizador, que articula a legislação, a doutrina e a jurisprudência a respeito dos elementos que integram o ambiente. Ele diz que não se trata mais de um direito apenas das águas, da atmosfera, o direito solo, um direito florestal, um direito da fauna ou ainda um direito da biodiversidade, pois o direito ambiental busca interligar esses temas com a argamassa da identidade das ferramentas jurídicas relacionadas à prevenção, à reparação, à informação, ao monitoramento e à participação.

O direito ambiental está ligado, também, com o desenvolvimento econômico brasileiro e com o desenvolvimento social, não apenas com a preservação do meio ambiente, pois o propósito não é apenas a preservação ambiental. O direito ambiental não visa em momento algum parar com qualquer tipo de desenvolvimento socioeconômico, e sim o oposto disso, uma vez que se o desenvolvimento tiver que desacelerar poderá produzir indiretamente uma maior agressão ao meio ambiental, já que é possível esperar que ocorram atividades irregulares, se não houver uma conciliação entre a preservação e o desenvolvimento socioeconômico. 


\section{Política ambiental}

A política ambiental no Brasil está atrelada em cima de dois princípios, os quais vão orientar qualquer conteúdo do direito ambiental. Esses princípios que norteiam o direito ambiental são o princípio da prevenção e o princípio do poluidor pagador.

Princípio da Prevenção: A recuperação de um dano ambiental, se possível, leva um longo período, com pouquíssimas exceções, que chegam a ser raras. O melhor mesmo para a política ambiental no Brasil é sempre evitar que o dano aconteça, pois, toda a legislação brasileira se norteia em evitar o dano e, após tentar corrigi-lo, puni-lo.

Por isso, o princípio da prevenção é que vai nortear toda a matéria ambiental, particularmente no que se refere às licenças ambientais. Para que seja concedido o licenciamento ambiental, criou-se um procedimento para que toda e qualquer atividade que possa gerar danos ao meio ambiente seja evitada. Para isso, então, a necessidade de haver um complexo procedimento para a liberação desses licenciamentos.

O princípio da prevenção sempre será aplicado quando houver perigo certo, quando realmente se pode afirmar que existem provas de que determinada atividade seja danosa ao meio ambiente. Por isso, os objetivos do direito ambiental são fundamentalmente preventivos, já que se deve voltar para os acontecimentos que antecedem o dano para, assim, poder evitá-los. A prevenção sempre vai ser a melhor solução, pois muitos danos para a ciência serão irreparáveis, apesar da punição, até mesmo quando for excessivamente onerosa.

A degradação ambiental, como regra, é irreparável. Como reparar o desaparecimento de uma espécie? Como trazer de volta uma floresta de séculos que sucumbiu sob a violência do corte raso? Como purificar um lençol freático contaminado por agrotóxicos? '. Claro que com algumas providências, muitos dos danos ambientais põem ser reparáveis. Mas, sob a visão da ciência e da técnica, podem ser irreparáveis.

O princípio da prevenção, na realidade, tem como objetivo impedir que ocorra o dano, através de medidas que sejam acautelatórias, antes que sejam implantadas quaisquer atividades que gerem potencial e evidente perigo, ocasionando poluição. $\mathrm{O}$ art. $225, \S 1, \mathrm{IV}$, CF/88, é um exemplo da prevenção.

Junto do princípio da prevenção existe, também, o princípio da precaução, que muitos pensam ser o mesmo conceito. O princípio da precaução teve muito mais força com a Declaração da Rio 92, em seu princípio n 15, que diz: "Para que o ambiente seja protegido, serão aplicadas pelos Estados, de acordo com as suas capacidades, medidas preventivas. Onde existam ameaças de riscos graves ou irreparável, não será utilizada a falta de certeza científica total como razão para o adiamento de medidas eficazes, em termos de custo, para evitar a degradação ambiental".

O princípio da precaução está ligado à proteção do meio ambiente e à segurança e integridade da vida humana. É um princípio que objetiva a busca antecipada do ato que pode causar o dano ambiental. O princípio da precaução será usado quando as informações científicas forem insuficientes para conformar que possa haver indicações de possíveis efeitos degradantes sobre o meio ambiente, às pessoas, aos animais ou até mesmo à proteção vegetal, de potencial perigo e incompatível com o nível proteção escolhido.

Esse princípio se baseia em elementos hipotéticos, sendo possibilidades e não fatos concretos cientificamente, mas nada conclusivo. $\mathrm{O}$ uso desse princípio pode ser em 
questões como o de aquecimento global, a engenharia genética e os organismos geneticamente modificados, a clonagem, e outros. Essas incertezas trabalham em favor do meio ambiente, levando ao interessado o ônus de provar ações pretendidas não ocasionaram consequências indesejadas.

Princípio do Poluidor-Pagador: para entender como esse princípio surgiu é necessário refletir sobre os problemas ambientais que os homens enfrentam e que são os mesmos que atualmente se confronta. Além disso, a industrialização trouxe alguns problemas ao meio ambiente e foi por causa disso que se começou a procurar meios de desenvolvimento mais sustentáveis e econômicos.

O Direito Ambiental encontra nesse princípio, com o ordenamento jurídico nacional e internacional, um meio de conseguir proteger o meio ambiente, mas com caminhos que sejam possíveis também o desenvolvimento entre as atividades industriais e o meio ambiente, buscando um equilíbrio entre ambos. Primeiramente, o Princípio do Poluidor pagador está na Declaração do Rio de Janeiro, no seu princípio $n^{\circ} 16$, quando afirmou que:

As autoridades nacionais devem procurar promover a internacionalização dos custos ambientais e o uso de instrumentos econômicos, tendo em vista a abordagem segundo a qual o poluidor deve, em princípio, arcar com o custo da poluição, com a devida atenção ao interesse público e sem provocar distorções no comércio e nos investimentos internacionais. (Declaração do Rio sobre meio ambiente e desenvolvimento, 1992)

A lei 6.938/81, de 31 de agosto de 1981, também acolheu tal princípio, ao colocá-lo como um dos objetivos da Política Nacional do Meio Ambiente, que trata sobre "a imposição ao usuário, da contribuição pela utilização dos recursos ambientais com fins econômicos e da imposição ao poluidor e ao predador da obrigação de recuperar e/ou indenizar os danos causados".

O Princípio do Poluidor-Pagador é normativo de natureza econômica, porque impõe ao poluidor os custos consequentes da atividade poluidora. Porém, para que haja o fortalecimento de resultados positivos na preservação do meio ambiente, é necessário que esse princípio seja considerado uma regra, com bom senso tanto politicamente, juridicamente e economicamente.

A definição de poluidor está no artigo. $3^{\circ}$, inciso IV, da lei 6.938/81, que diz: "poluidor: a pessoa física ou jurídica, de direito público ou privado, responsável direta ou indiretamente por atividade causadora de degradação ambiental". Também no artigo. 225 da Constituição Federal está definido quem pode figurar o polo passivo de determinada ação ambiental. Ao determinar no próprio ordenamento jurídico "é dever do Poder Público e da coletividade preservar e defender o meio ambiente". Diante disso, pode-se concluir que tanto a coletividade quanto o próprio Poder Público podem ser classificados como legitimado passivo, isto é, o poluidor.

Os princípios são uma base para um específico ramo do Direito, são o alicerce para toda construção de mecanismos vitais ao uso de um Sistema Jurídico. O meio ambiente de qualidade se colocou ao nível de direito fundamental do ser humano, ou seja, um meio ecologicamente equilibrado de boa qualidade de vida.

Isso acontece porque existe apreensão no que diz respeito à preservação ambiental relativa ás gerações atuais e, muito além disso, comprometendo o futuro das próximas. 
Contudo, os problemas consequentes dos danos não se fixam apenas ao local do acontecido, pois a degradação do meio ambiente pode gerar problemas de espera global, mesmo que ocorra em um país isolado. Conforme o grande autor Paulo de Bessa Antunes (2016):

\footnotetext{
Os princípios ambientais insculpidos na Lei Maior estão voltados para a finalidade básica de proteger a vida, em qualquer forma que está se apresente, e garantir um padrão de existência digno para os seres humanos desta e das futuras gerações, bem como de conciliar os dois elementos anteriores com o desenvolvimento econômico ambientalmente sustentável.
}

Ubiquidade - Significa a chance de estar presente em vários lugares ao mesmo tempo. Caracteriza a ideia de onipresença.

Sustentabilidade - Não se trata de estabelecer um tipo de utopia se não, sobre critérios pragmáticos, de tornar adaptável o progresso econômico necessário para que nossos similares e seus herdeiros possam viver decentemente com o respeito de arredores biofísicos apropriados.

Sustentabilidade é uma forma usada para determinar ações e atividades humanas que se destinam a preencher as necessidades existentes dos seres humanos, sem comprometer a vida das próximas gerações. Ou seja, a sustentabilidade está justamente ligada ao desenvolvimento econômico e material sem acometer o meio ambiente, utilizando os recursos naturais de forma engenhosa para que eles se preservem no futuro. Acompanhando estes fatores, a humanidade pode assegurar o avanço sustentável

Subsidiariedade - Próximo ao da globalidade a subsidiariedade se coincide com outro extremo do alforismo "pensar globalmente e atuar local".

Solidariedade - Este princípio tem essencial validade e atuação, pelo que teria que se esperar razoável efetividade nos círculos sociais gradativamente desenvolvidos. Sua excelência para a tutela do ambiente lida em uma dupla área: a intercomunitária e a Inter gerencial. Há também conceitos do direito ambiental que são necessários à sua observação e que estão consolidados na Declaração do Rio/92. Além dos princípios da prevenção, precaução e do princípio do poluidor-pagador existe mais alguns que também merecem destaque, são eles:

Obrigatoriedade da Intervenção Estatal - Diz que se deve confiar, às entidades nacionais habilitadas, a tarefa de planificar, administrar e controlar o uso dos recursos naturais dos Estados, com o propósito de melhorar as circunstâncias de vida do meio ambiente.

Informação - Todo o indivíduo tem direito a todas e quaisquer informações referentes ao meio ambiente em todo o território nacional, especialmente quando se tratar de atividade perigosa na região em que vive. Um exemplo disso é de quem mora perto de locais de tratamento de resíduos, esses têm direito a todas informações referentes ao desempenho dessa atividade, ainda mais quando pode afetar a sua saúde e bem-estar.

Participação/Recuperação - Quando Estado e Sociedade devem somar esforços para preservar o meio ambiente, englobando nisso, informar.

\section{TIPOS DE RESPONSABILIDADE}

Após constatado o dano, é preciso para que haja a reparação ou seu ressarcimento, a comprovação da responsabilidade do autor. É unânime no direito que a incumbência de 
reparar seja uma fonte obrigacional, fazendo que o gerador assuma por qualquer dano a pessoas ou ao bem da vítima. A responsabilidade, no que se refere á categoria jurídica, pode ser pessoa física ou jurídica, e que se vier a infringir norma ou preceito do direito objetivo, comprovada a infração, ficará sujeita a determinada sanção.

Em percepção vasta, a concepção de responsabilidade civil é dividida em dois aspectos: a) Responsabilidade Contratual, a qual sucede de desobediência ao contrato, ocasionando prejuízo aos contratantes, conforme o artigo. 389 do Código Civil "Não cumprida a obrigação, responde o devedor por perdas e danos, mais juros e atualização monetária segundo índices oficiais regularmente estabelecidos e honorários de advogado” b) Responsabilidade extracontratual, ou também aquiliana, a qual entende por ser aquele que o agente não está conectado com a vítima, por contrato, e decorre o preceito compreendido no artigo. 927 do Código Civil "Aquele que, por ato ilícito (art. 186 e 187) causar dano a outrem, fica obrigado a repará-1o".

Existe a teoria objetiva e a subjetiva no que diz respeito ao direto ambiental: na teoria subjetiva é preciso, para responsabilizar alguém provar a culpa do agente, ou seja, a imprudência, negligência e a imperícia, além disso, o comportamento que teria iniciado tudo, que pode ser comissivo ou omissivo, além do dano e o nexo causal. Diferente do que ocorre na teoria subjetiva, a teoria objetiva exige responsabilidade de consertar o dano mesmo que não haja culpa por parte do agressor, baseando-se no prejuízo e no nexo causal, podendo em alguns casos a culpa ser pressentida.

Entre os tipos de teoria do risco está a teoria do risco integral a qual requer a indenização pelo simples motivo de encontrar-se a atividade potencialmente poluidora da qual adveio o dano, não se permitindo nenhuma excludente da obrigação de reparar o dano. Importante salientar que o Código Civil assumiu a teoria do risco integral utilizando a responsabilidade objetiva (parágrafo único do art. 927 do CC/2002).

Dessa forma, depois de entender os tipos de responsabilidade, é viável a compreensão da definição da teoria empregada no direito ambiental brasileiro.

\subsection{A responsabilidade ambiental}

Considerando a realidade que o teor ambiental abrange interesses difusos, o entendimento da questão acerca da matéria ambiental sempre foi de amplo destaque para o ressarcimento do dano.

Pessoa jurídica é a unidade de pessoas naturais ou de patrimônio, que visa à consecução de certos fins, reconhecida pela ordem jurídica como sujeito de direitos e obrigações. Aqui, o dano ambiental é versado sobre o prisma da responsabilidade civil, que pode ocasionar aos seus agentes infratores, se tratando de pessoa jurídica, e quais meios processuais são aplicados para os meios de reparação.

O direito do Brasil, referente ao dano ambiental, está muito bem especificado a respeito da responsabilidade civil por danos gerados ao meio ambiente. A responsabilidade civil no ramo do direito ambiental contraiu vasta dimensão no Brasil. A lei 6.938/81, da Política Nacional do Meio Ambiente, criou a alternativa de responsabilizar o causador do dano, no meio civil, decorrente de ações lesivas à qualidade de vida ambiental, e isto, foi ainda fortalecida pelo art. 225, $\S 3$ da CF. Quando se estabeleceu a teoria objetiva na matéria de 
dano ambiental, o querer do autor não interessa, o que realmente importa é a correlação entre o dano e a causalidade.

Ou seja, na teoria objetiva o causador do dano deverá responder mesmo que não tenha havido culpa de sua parte. A teoria da qual falamos, está enunciada na lei 6.938/81, no artigo 14, $\S 1$. A legitimidade para propor a ação de responsabilidade civil por danos ao meio ambiente cabe ao Ministério Público da União e dos Estados. É claro que, quando devidamente executada, a responsabilidade civil faz que o responsável pela degradação adquira instrumentos que busquem impedir ou reduzir as ações negativas.

Quando se institui que a responsabilidade objetiva ocorre independentemente de culpa, estabelece ao causador do dano o risco por suas atividades.

Para muitos autores, a força maior, o caso fortuito, assim como fato de terceiro não tiram a responsabilidade dos danos que foram gerados ao meio ambiente. Um exemplo, é quando ocorrem danos nucleares, nos quais pode haver impedimentos para reconhecer quem é autor que o gerou, porque pode se tratar de muitas indústrias. Nesse caso, aplica-se a solidariedade passiva (art.942 do Código Civil). Dessa forma, toda vez que existir dois ou mais agentes causadores do dano, todos então terão que responder solidariamente.

Há ainda danos que são provenientes de emissões desconhecidas ou acumuladas. Ademais, alguns casos só apresentam o resultado danoso depois de longos períodos, como é caso dos danos atmosféricos ou da poluição de recursos hídricos.

De acordo com o artigo $4^{\circ}$ da Lei dos Crimes Ambientais, há a possibilidade que se desconsidere a personalidade jurídica, se for necessário para a reparação dos estragos à qualidade do meio ambiente. E, se ocorrer falta de bens da empresa, poderá então passar a pegar patrocínios dos próprios sócios. Importante saber que a responsabilidade da pessoa jurídica não tira a responsabilidade da pessoa física.

\section{TUTELA JURÍDICA AMBIENTAL}

A Lei 6.938/81, o meio ambiente, finalmente, alcançou sua proteção no Brasil. Esta lei é a maior expressão para a política do meio ambiente, também seguida da Lei Federal 7.347/85, que trata sobre a Ação Civil Pública Ambiental e a CF/88. A Lei da Política Nacional do Meio Ambiente considera o meio ambiente como um bem público que precisa ser protegido e segurado, visando que é um bem de uso coletivo.

\section{Formas processuais para a proteÇÃo do Meio ambiente}

Há diversos meios para a proteção ao ambiental. Além da forma penal, também poderão ser usadas ações ordinárias, mandado de injunção, mandado de segurança e outros. Todavia, a forma mais utilizada é a ação civil pública e a ação popular.

\subsection{Ação popular}

Está prevista no artigo $5^{\mathrm{a}}$ da CF. a ação popular que, entre outras finalidades, também pode ser usada na defesa do meio ambiente, conforme enuncia a lei 7.347/85, em seu artigo 
1, caput, que referencia "Regem-se pelas disposições desta Lei, sem prejuízo da ação popular, às ações de responsabilidade por danos morais e patrimoniais, causados."

A ação popular é um instrumento disponível a todo cidadão, tornando-o um fiscalizador do bem comum e auxiliando na extinção e diminuição dos atos lesivos ao meio ambiente. Para que isso possa ocorrer, o cidadão precisa entrar perante juízo, o direito coletivo de interesse público ${ }^{2}$.

A caraterística essencial da ação popular é a cidadania como requisito de impetração da ação. Então, o cidadão deve ser eleitor e estar no gozo dos seus direitos políticos, ou seja, dos direitos de votar e ser votado. A rigor, basta qualidade de eleitor (Art. $1 .^{\circ}, \S 3 .^{\circ}$, da Lei 4.717/65), exige que a prova da cidadania, para ingresso em juízo, seja feita com o título de eleitor, ou com documento que a ele corresponda.

O objetivo da ação popular é lutar contra o dano e não ser usada para a reparação do mesmo. E um remédio constitucional eficiente para ser manejado, pois pode ser utilizado preventiva e repressivamente.

\subsection{Ação civil pública}

Essa ação tem por propósito resguardar os interesses do cidadão e da sociedade. As demandas ambientais infelizmente são demoradas, e sem julgamento, mas conduzem as companhias a realizar programas de preservação no combate e controle da degradação. A ação civil pública foi criada com a finalidade de beneficiar a sociedade com um meio jurídico apto a transformar efetiva suas propensões pertinentes ao meio ambiente, por meio, do Poder Judiciário.

Disciplina a ação civil pública de responsabilidade por danos causados ao meio ambiente, ao consumidor, a bens e direitos de valor artístico, estético, histórico, turístico e paisagístico. Art. $1^{\circ}$ Regem-se pelas disposições desta Lei, sem prejuízo da ação popular, as ações de responsabilidade por danos causados: I - ao meio ambiente (Lei N $\mathrm{N}^{\mathrm{0}}$ 7.347, DE 24 DE JULHO DE 1985)

No campo dos direitos humanos, o meio ambiente é considerado direito difuso. Quando se fala em direitos difusos, são aqueles direitos transindividuais de natureza indivisível, que abrangem número indeterminado de pessoas unidas pelas mesmas circunstâncias de fato. Já os direitos coletivos em sentido estrito consistem em direitos transindividuais, de natureza indivisível, de que seja titular grupo, categoria ou classe de pessoas ligadas entre si ou com a parte contrária por uma relação jurídica base. A característica fundamental dos direitos difusos é a indeterminabilidade dos titulares, ao contrário dos direitos coletivos em sentido estrito, cujos titulares são determinados ou determináveis justamente pela vinculação a uma relação jurídica base. (RAMOS, 2017, p. 69)

2 Outros dois elementos característicos básicos, são importantes: o fato de que a sua titularidade cabe a qualquer cidadão e o de que este age na defesa do interesse público e não de interesse individual. Na ação popular, o autor pede a prestação jurisdicional para defender o interesse público, razão pela qual tem sido considerado como um direito de natureza política, já que implica controle do cidadão sobre atos lesivos aos interesses que a Constituição quis proteger. Entretanto, caso seja promovida a ação no exercício de direito subjetivo próprio, poderá a ação ser julgada improcedente, por falta de interesse de agir. (MANCUSO, 2001, p. 132). 
Como exemplo de direito difuso de titularidade indeterminada (toda a coletividade social), o STF reconheceu que o direito à "integridade do meio ambiente - típico direito de terceira geração - constitui prerrogativa jurídica de titularidade coletiva, refletindo, dentro do processo de afirmação dos direitos humanos, a expressão significativa de um poder atribuído, não ao indivíduo identificado em sua singularidade, mas, num sentido verdadeiramente mais abrangente, à própria coletividade social" (MS 22.164, Rel. Min. Celso de Mello, julgamento em 30-10- 1995, Plenário, DJ de 17-11-1995)

A lei 7.347/85, traz em sua redação a ação civil pública. Esse tipo de ação pode usado para reparar o dano e para prevenir o dano ambiental. O Ministério Público, as pessoas de direito público interno, as suas paraestatais e as associações ambientalistas constituídas por pelo menos um ano possuem legitimidade ativa.

$\mathrm{O}$ artigo $3^{\mathrm{a}}$ da lei da ação civil pública diz que a punição pode ocorrer, por meio da pena em dinheiro, do pagamento de indenização e também com a ordem para cumprir a obrigação de fazer ou não fazer. Enfim, o objetivo dessa ação é de resgatar ou, pelo menos, tentar restaurar os bens e interesses no seu aspecto individual. A sentença nessa ação terá efeito erga omnes, nos marcos da competência territorial do órgão que proferiu.

Sobre o inquérito civil, vale dizer que ele não é obrigatório, pois se o Ministério Público tiver os dados essenciais, ele mesmo poderá providenciar a ação civil pública, mesmo que não tenha ocorrido o inquérito. Mas, se for feito o inquérito, o prazo para seu término é de 90 dias.

A lei referente à ação civil pública também elaborou outra ferramenta judicial, o fundo eminentemente preventivo, que é denominado como compromisso de ajustamento de conduta, que está previsto no artigo. $5^{\circ}, \mathrm{VI}$, da lei. Esse ajustamento de conduta tem por finalidade estipular normas quanto ao seu cumprimento, para fazer que o agente do dano cumpra com o seu dever, sujeitado á análise do Ministério Público ${ }^{3}$.

\section{REPARAÇÃo DO DANO}

Após ser verificado o dano pelo poluidor é, sem dúvida, imprescindível a reparação do dano. E, se isso não acontecer, lamentavelmente as consequências se alastrarão até as próximas gerações.

É fundamental que o infrator seja responsabilizado, pois só assim ocorrerá a reparação do dano que o mesmo causou ao meio ambiente. A principal consequência da responsabilidade civil, certamente é a reparação do dano. Entre as imposições que existem para a restauração do dano, é indiscutível que a obrigação de reparar o dano é a que encontra mais dificuldades, em relação às condenações penais e administrativas, já que é difícil determinar quem causou a poluição ou a deterioração.

3 Tratando-se de indenização por danos morais em razão de ofensa a interesses difusos ou coletivos stricto sensu, os recursos obtidos serão destinados ao Fundo de Defesa de Direitos Difusos, previsto no artigo 13 da Lei 7.347/85, ou para outros fundos específicos, como o Fundo de Amparo ao Trabalhador (no caso de danos verificados na seara trabalhista) ou o Fundo dos Direitos da Criança e do Adolescente (se a lesão atingir essas classes de pessoas). Esta parece ser a sistemática mais adequada, pois os recursos de tais fundos são empregados na adoção de medidas tendentes à proteção e à recomposição de direitos coletivos lesados. Ademais, como os recursos são destinados aos mencionados fundos, afasta-se o argumento de que indenizações de vulto acarretariam o enriquecimento sem causa do autor da ação, alegação muito comum dos réus das demandas por danos morais (KOSAKA 2009, p. 85) 
O artigo 4, §VII da lei 6.938/8 trouxe para o ordenamento jurídico um preceito sobre a obrigação, que se deve recuperar e/ou indenizar, estragos trazidos ao meio ambiente. Assim, quem responderá pelo dano são as pessoas que, direta ou indiretamente, tenham ocasionado o ato danoso. Porém, no que diz respeito às pessoas jurídicas de direito privado, são incumbidas em qualquer tipo que se constituem.

A reparação do dano no direito ambiental pode acontecer de duas formas: por meio da reparação da condição que se tinha antes do dano ou a indenização feita em dinheiro. Quando o dano for tão agressivo que a reparação de seu estado anterior for impossível, ocorrerá então a indenização pecuniária, estes valores serão conhecidos por meio de arbitramento, de acordo com o Código Civil (art.950, parágrafo único). Esse arbitramento se mede conforme a propagação do dano no meio ambiente.

\section{CONSIDERAÇões FINAIS}

A responsabilização do dano causado pelo infrator, nesse caso de pessoa jurídica, é muito importante para que possa haver a reparação da degradação, para que está não venha respingar suas consequências nas futuras gerações. A forma como a pessoa jurídica será punida, ocorrerá pela reparação do dano ou por sua indenização em dinheiro. Entretanto, apenas incidirá a indenização pecuniária se não houver possibilidade de restaurar o dano sobre o meio ambiente e o estado que se achava anteriormente.

A punição será solidária caso não se possa definir o exato autor do dano.

Todas as regras sobre o tema estão dispostas na Constituição, no artigo. 225 e nas leis 6.938/81 e $7.347 / 85$, as quais garantem o direito á qualidade ao meio ambiente, que é de bem comum, coletivo a todos os cidadãos. No Brasil, foi adotada a teoria da responsabilidade objetiva em relação aos danos ambientais. Tal responsabilidade incide na reparação do dano, independentemente da culpa do infrator, que é fundada no risco integral, que busca a eficácia da reparação e a indenização dos prejuízos causados ao meio ambiente, sem que a parte lesada tenha que comprovar a culpa do agente.

Portanto, é necessário e preciso a conscientização de todos na preservação do meio ambiente, posto que é um direito previsto fundamental ao ser humano. E, se ainda assim, ocorrer degradação a esse bem de uso comum, é imprescindível a penalização por parte do órgão responsável, por intermédio dos instrumentos disponíveis na lei, a fim de que haja, sim, a punição e que, em consequência disso, ocorra a reparação e/ou a indenização do dano o qual, por bem ou por mal, ressarcirá uma parte do que foi devastado. Contudo, é importante que se utilize mais continuamente o princípio da prevenção para que possa evitar o dano ou parte dele antes que se destrua por inteiro.

\section{REFERÊNCIAS}

ADVOGADOS, Associação Brasileira. Conceito e Classificação das Pessoas Jurídicas. Disponível em: https://aba.jusbrasil.com.br/noticias/176597777/conceito-e-classificacao-daspessoas-juridicas. Acesso em: 1 maio de 2017. 
ALVES, Tassiane Alexandre. Princípios de Direito Europeu da Responsabilidade Civil (PETL) sobre o nexo causal e sua potencial aplicação ao Direito Brasileiro. http://www. pucrs.br/direito/informacoes-academicas/trabalho-de-conclusao-de-curso/artigos-publicados-a-partir-do-resumo-de-trabalhos-de-conclusao-de-curso. Data de acesso: 15.08.2020.

ANTUNES, Paulo Bessa. Direito ambiental. $18^{\circ}$ ed., revista, atualizada e ampliada. São Paulo, Atlas, 2016.

BECKER, Rosane. A Responsabilidade Civil da Pessoa Jurídica por Dano Ambiental. Título Disponível em: https://www.univates.br/media/graduacao/direito/RESPONSABILIDADE_CIVIL_DA_PESSOA_JURIDICA_DANO_AMBIENTAL.pdf Acesso em: 18 abr. 2017.

BENJAMIN, Antônio Herman V. Responsabilidade civil pelo dano ambiental. Revista de Direito Ambiental. São Paulo, n. 9, p. 5-52.

BERTOLI, Célia Henriques Guércio Rodrigues Vagner . AMBIENTE JURÍDICO Responsabilidade civil ambiental e a reparação integral do dano. Disponível em: $<$ http:// www.eduvaleavare.com.br/wpcontent/uploads/2014/07/responsabilidade_civil.pdf $>$. Acesso em: 18 abr. de 2017.

BRASIL. Lei n ${ }^{\circ} 6.938$ de 1981: Dispõe sobre a Política Nacional do Meio Ambiente. Disponível em: http://www.planalto.gov.br/ccivil_03/leis/L6938.htm Acesso em: 20 mai 2017.

BRASIL. Lei $n^{\circ} 7.347$ de 1985: Disciplina a ação civil pública de responsabilidade por danos causados ao meio-ambiente, ao consumidor, a bens e direitos de valor artístico, estético, histórico, turístico e paisagístico. Disponível em: http://www.planalto.gov.br/ ccivil_03/leis/L7347orig.html Acesso em: 10 mai 2017.

BRASIL. Constituição Federal do Brasil: estabelece os princípios da política nacional do meio ambiente. 1988.

CENCI, Daniel Rubens. Direitos Humanos, Meio Ambiente e Novos Direitos. Coleção Direitos Humanos e Democracia. Unijuí, 2014.

COLOMBO, Silvana Raquel Brendler. A Reponsabilidade Civil no Direito Ambiental. Disponível em: <http://www.ambitojuridico.com.br/site/?n_link=revista_artigos_leitura\&artigo_id=1413>. Acesso em: 15 jun. 2017.

CORIOLANO, Caroline Pires. Princípios Fundamentais do Direito Ambiental. Disponível em: <http://www.conteudojuridico.com.br/artigo,principíos-fundamentais-do-direitoambiental,40030.html>. Acesso em: 5 de mai 2017. 
COSTA, Kalleo Castilho. Ação Popular e Ação Civil Pública. Disponível em: <http:// www.ambitojuridico.com.br/site/revista_artigos_leitura\&\&artigo_revista_caderno=9 $>$. Acesso em: 1. ${ }^{\circ}$ mai 2017.

COELHO, Fábio Ulhoa. Curso de direito civil, volume 2: obrigações: responsabilidade civil. - 5. ed. - São Paulo: Saraiva, 2012

CUSTÓDIO, Helita Barreira. Avaliação de custos ambientais em ações judiciais de lesão ao meio ambiente. Revista dos Tribunais, v. 652, p. 26.

DECLARAÇÃO DO RIO SOBRE MEIO AMBIENTE E DESENVOLVIMENTO. Disponível em: http://www.onu.org.br/rio20/img/2012/01/rio92.pdf Acesso em: 20 jun 2017.

FURASTÉ, Pedro Augusto. Normas Técnicas para o Trabalho Científico: Explicação das Normas da ABNT, 17 ed. Porto Alegre: Dáctilo Plus, 2015.

GIL, Antônio Carlos. Como elaborar projetos de pesquisa. 4. ed. São Paulo: Atlas, 2008.

JUNIOR, José Luiz. Responsabilidade Civil por Danos Ambientais Disponível em: http:/www.direitonet.com.br/artigos/exibir/1934/Responsabilidade-civil-por-danosambientais Acesso em 13 mai 2017.

KOSAKA, Fausto Kozo. Apontamentos sobre Dano Moral Coletivo. Cadernos de Direito, Piracicaba, v. 9(16-17): 75-91, jan.-dez. 2009

LIMA, Jesildo Moura de. Impactos da aplicação de financiamentos no processo de desenvolvimento da agricultura no município de Independência - RS / Jesildo Moura de Lima. Ijuí, 2012.

MANCUSO, Rodolfo de Camargo. Ação Popular. Proteção do erário, do patrimônio público, da moralidade administrativa e do meio ambiente. São Paulo: Editora Revista dos Tribunais, 2001.

MENDES, Gilmar Ferreira. Curso de Direito Constitucional. - 1 D. ed. rev. e atual. - São Paulo: Saraiva, 2015.

MIRRA, Álvaro Luiz Valery. AMBIENTE JURÍDICO Responsabilidade civil ambiental e a reparação integral do dano. Disponível em: <http://www.conjur.com.br/2016-out-29/ ambientejuridico-responsabilidade-civil-ambiental-reparacao-integral-dano $>$. Acesso em: 10 mai 2017.

OLIVEIRA, Marcelo Viana de. A tríplice responsabilidade por danos causados ao meio ambiente. Conteúdo Jurídico, Brasília-DF: 03 out. 2012. Disponível em: <http://www. conteudojuridico.com.br/?artigos\&ver=2.39777\&seo=1>. Acesso em: 1 mai 2017. 
RAMOS, André de Carvalho. Curso de direitos humanos. São Paulo: Saraiva, 2017.

REMÉDIO, José Antônio. BARBOSA, Karin de Andrade. A educação ambiental como instrumento de proteção do direito fundamental ao meio ambiente. Cadernos de Direito, Piracicaba, v. 13(25): 9-24, jul.-dez. 2013.

SIRVINSKAS, Luís Paulo. Manual de direito ambiental. 13. ed. São Paulo: Saraiva, 2015.

SMANEOTO, Cecília. A responsabilidade socioambiental e a sustentabilidade como nova fronteira para o cooperativismo agropecuário / Cecília Smaneoto. Ijuí, 2012.

\section{DADOS DO AUTOR}

\section{MÁrcio Bonini Notari}

Graduado em DIREITO pela Universidade Católica de Pelotas (2008). Especialização em Direito e Processo do Trabalho pela Anhanguera RS (2010) e Mestrado em Direito pela Universidade de Santa Cruz do Sul (2015).marciobnotari@gmail.com

Submetido em: 9-8-2019

Aceito em: 14-8-2020 